University of Nebraska - Lincoln

DigitalCommons@University of Nebraska - Lincoln

\title{
Gas Chromatography/Mass Spectrometry Analysis of the Cuticular Hydrocarbons from Parasitic Wasps of the Genus Muscidifurax
}

\author{
Ulrich R. Bernier \\ University of Florida, ubernier@gainesville.usda.ufl.edu \\ David A. Carlson \\ United States Department of Agriculture-Agricultural Research Service \\ Christopher J. Geden \\ United States Department of Agriculture-Agricultural Research Service, Chris.geden@ars.usda.gov
}

Follow this and additional works at: https://digitalcommons.unl.edu/usdaarsfacpub

Part of the Agricultural Science Commons

Bernier, Ulrich R.; Carlson, David A.; and Geden, Christopher J., "Gas Chromatography/Mass Spectrometry Analysis of the Cuticular Hydrocarbons from Parasitic Wasps of the Genus Muscidifurax" (1998).

Publications from USDA-ARS / UNL Faculty. 955.

https://digitalcommons.unl.edu/usdaarsfacpub/955

This Article is brought to you for free and open access by the U.S. Department of Agriculture: Agricultural Research Service, Lincoln, Nebraska at DigitalCommons@University of Nebraska - Lincoln. It has been accepted for inclusion in Publications from USDA-ARS / UNL Faculty by an authorized administrator of DigitalCommons@University of Nebraska - Lincoln. 


\title{
Gas Chromatography/Mass Spectrometry Analysis of the Cuticular Hydrocarbons from Parasitic Wasps of the Genus Muscidifurax
}

\author{
Ulrich R. Bernier, David A. Carlson, and Christopher J. Geden \\ United States Department of Agriculture-Agricultural Research Service, Center for Medical, Agricultural, \\ and Veterinary Entomology, Gainesville, Florida, USA
}

\begin{abstract}
Parasitic Hymenoptera can be difficult to identify by conventional taxonomic techniques. Examination of the cuticular hydrocarbons (CHCs) provides a basis for chemotaxonomic differentiation, which may lead to the discovery of pheromones, and can be a means of examining colonies for species cross-contamination. The parasitic wasps examined were Muscidifurax raptor, M. zaraptor, M. uniraptor, and the gregarious form of M. raptorellus. Species within the genus Muscidifurax, as well as the sex, can clearly be differentiated by examining the gas chromatograms of the CHCs. Identification of the alkanes by mass spectrometry shows uncommon dimethylalkanes and trimethylalkanes for members of the genus. The methyl branched cuticular hydrocarbons of these insects are rare compared to those found on insects reported in the literature, but are present in significant amounts on these insects. Additionally, sexual dimorphism is observed in long chain alkanes $\left(\mathrm{C}_{21}-\mathrm{C}_{39}\right)$ present on male and female cuticular surfaces for these species. Females tend to have cuticular hydrocarbons with methyl branches located externally on the carbon backbone chain for dimethyl-, trimethyl-, and tetramethylalkanes, whereas males tend to have dimethyl- and trimethylalkanes located internally on the hydrocarbon backbone chains. Mass spectra of novel and rare methyl branched compounds identified on these parasitoids are presented. (J Am Soc Mass Spectrom 1998, 9, 320-332)
\end{abstract}

$\mathrm{I}$ ncreasing concern about the use of synthetic organic pesticides to control agricultural insect pests is 1 prompting the development of integrated pest management strategies that emphasize biological control. A method of biological control for house flies, widely used on poultry and dairy farms, is the disbursement of pteromalid wasps [1, 2]. Wasps in this family (Pteromalidae) do not sting or bite humans or animals but are entirely host specific for flies, attacking the puparia [3]. Pteromalid species vary in effectiveness against flies and are influenced by environmental and climatic effects.

Most of the indigenous parasitoids can readily be identified by morphological characters [3]. There is a need, however, for clearer taxonomic characters of exotic species contemplated for release in the United States. The wasps studied in this work are Muscidifurax spp. that are difficult to identify by taxonomic techniques [4]. Several are proven or potential biological control agents for filth fly infestations in the United States. There are five species that comprise this genus. $M$. raptor and $M$. zaraptor are of North American origin and are morphologically and biologically similar. $M$.

Address reprint requests to Dr. Ulrich R. Bernier, USDA-ARS-CMAVE, 1600 SW 23rd Drive, Gainesville, FL 32608. E-mail: ubernier@gainesville. usda.ufl.edu uniraptor is a unisexual female species originally identified in Puerto Rico. M. raptorellus is native to South America and has both a gregarious and solitary form. However, a gregarious strain of $M$. raptorellus was discovered recently in Nebraska [2]. M. rapteroides is restricted to Central America; therefore, this species was not examined here.

Starch gel electrophoresis of allozymes has been examined as a means of differentiating species in this genus, but a satisfactory degree of resolution was not achieved [5, 6]. Techniques such as RAPD-PCR [7] and mitochondrial DNA [8] have been successfully used to differentiate these closely related species. However, differentiation of $M$. uniraptor and $M$. raptorellus was difficult using mitochondrial DNA. Single insects were differentiated by quantitation from gas chromatography (GC), and variants of species, such as gregarious versus solitary forms of $M$. raptorellus, were differentiated by careful selection of the GC peaks as markers in a companion study [9]. The focus of this work is the identification of hydrocarbon components present on males and females of this genus, specifically examining patterns in the compounds that demonstrate the sexual dimorphism.

Demonstration of sexual dimorphism in the cuticular hydrocarbons (CHCs) of female and male insects can provide clues for the determination of a sex pheromone 
[10-13]. Additionally, CHCs have been used to differentiate species of beetles [14], mosquitoes [15], cockroaches [16], grasshoppers $[17,18]$, termites $[19,20]$, bees [21, 22], fruit flies [23], tsetse flies [11-13, 24], and others. The identification of CHCs by gas chromatography/mass spectrometry (GC/MS) allows the differentiation of four species of Muscidifurax by examining not only the gas chromatograms but also the mass spectra which clearly contain different compounds that demonstrate the sexual dimorphism in this species.

\section{Experimental}

The insects were collected from the following locations: M. uniraptor and M. zaraptor were taken from Nebraskan cattle feedlots and established as colonies in Nebraska in 1992, M. raptor was collected from a Florida dairy farm in 1994, and M. raptorellus (gregarious form) was obtained in 1995 from the USDA-ARS, Midwest Livestock Insects Laboratory, Lincoln, NE. Insects were dried and frozen prior to lipid extraction with hexane. Twenty insects of each sex and species (identified previously by morphological characters) were soaked in hexane for approximately $2 \mathrm{~h}$. The hexane fraction was placed on a silica gel column; the first $3 \mathrm{~mL}$ was eluted off the column with additional hexane and collected [15]. Nonhydrocarbon lipids remained on the column and were discarded. The hydrocarbon-containing fraction was concentrated to dryness with a stream of nitrogen. Each sample was injected in duplicate. The first sample contained approximately $2-3$ insect equivalents (an insect equivalent represents the amount of material collected from a hexane rinse of a single insect) in $1.0 \mu \mathrm{L}$ hexane, accomplished by reconstitution of the hydrocarbon residue with $10-15 \mu \mathrm{L}$ hexane. This provided a chromatogram without overloaded peaks, such that the Kovat's indices (KIs) values could accurately be determined. The second injection was performed after sample evaporation followed by reconstitution with 2.0-2.5 $\mu \mathrm{L}$ hexane. A $1.0 \mu \mathrm{L}$ injection was made, equaling 8 to 10 insect equivalents. The second analysis gave quality mass spectra for trace level compounds although the column was overloaded for the larger peaks.

Mass spectra and chromatograms were obtained by a HP 5988A mass spectrometer interfaced to a HP 5890 series II GC (Hewlett-Packard, Atlanta, GA); the GC injection port was fitted with an OCI-3 cold on-column injector (SIS, Inc., Ringoes, NJ). The column was a $30 \mathrm{~m}$ $\times 0.32 \mathrm{~mm}$ i.d. DB-1 FSOT column $\left(d_{f}=0.25 \mu \mathrm{m}\right)(\mathrm{J} \& \mathrm{~W}$ Scientific, Folsom, CA) attached to a retention gap with a $5 \mathrm{~m} \times 0.53 \mathrm{~mm}$ i.d. deactivated FSOT guard column (Restek, Bellefonte, PA). The column linear velocity was set to approximately $50 \mathrm{~cm} / \mathrm{s}$ at $60{ }^{\circ} \mathrm{C}$. The GC ramp consisted of a $2 \mathrm{~min}$ hold at $60^{\circ} \mathrm{C}$, a ramp at $10^{\circ} \mathrm{C} / \mathrm{min}$ to $220^{\circ} \mathrm{C}$, then $3{ }^{\circ} \mathrm{C} / \mathrm{min}$ to $310^{\circ} \mathrm{C}$, and a hold at $310{ }^{\circ} \mathrm{C}$ to elute all components.

The ion source was operated in electron ionization (EI) mode with an electron energy of $70 \mathrm{eV}$ and ion source temperature of $150{ }^{\circ} \mathrm{C}$. The mass spectrometer tune parameters were optimized with perfluorotributylamine (PFTBA) to enhance the $m / z$ 200-500 region, containing the $m / z 219$ and $m / z 502$ ions, relative to the $m / z 69$ ion. The mass spectral scan range extended from $m / z 50$ to $m / z 700$ with a scan rate of $1.8 \mathrm{~s}$ per scan. Interpretation of the mass spectra followed previously established conventions [11-13, 25-27]. These references describe the interpretation process and location of methyl branched positions for natural hydrocarbons, synthesized de novo, for which there are no synthetic equivalents.

Full names of the compounds identified will not be used throughout this manuscript. Instead, a shorthand nomenclature will be used based on locations of methyl substitutions and the number of carbons in the backbone chain length, reported as $\left(m_{1}, m_{2}, m_{3}, m_{4}\right.$, $-\mathrm{Me}_{y} \mathrm{C}_{x}$ ) where $m_{1}-m_{4}$ represent the locations of methyl branches on the carbon backbone chain (numbered by IUPAC convention), $y$ represents the number of methyl branches, and $x$ represents the number of carbons in the chain backbone. For example, 3,7,11,15-tetramethylpentatriacontane is written as $3,7,11,15-\mathrm{Me}_{4} \mathrm{C}_{35}$ with the understanding that there are a total of 39 carbons in this compound, 35 of which are in the backbone chain.

The use of retention indices or Kovat's indices provides a rapid means of identifying homologous series of branched methylalkanes. It should be noted that these four digit values are not true KIs because they were not obtained under isothermal GC conditions. Instead, they are calculated from interpolation between the peak retention times of a standard containing $n$-alkanes. The standard used for this work consisted of $n$-alkanes from $\mathrm{C}_{12}-\mathrm{C}_{36}$, plus $15,19,23-\mathrm{Me}_{3} \mathrm{C}_{37}$ (KI 3770), at concentrations of $50-300 \mathrm{ng} / \mu \mathrm{L}$ each in hexane. The standard was analyzed prior to acquisition of data as a means of diagnosing instrument operation conditions as well as providing the template for calculating KI values. Homologous series of methylalkanes shift to lower KI values as the carbon backbone chain increases in length [28]. In this work, the reported values are adjusted slightly to maintain consistent values for each series of methyl substitutions. An example of the KI values used in this manuscript is the series of internally branched dimethylalkanes, such as the 13,17-dimethylalkanes. The earliest eluting 13,17-isomer occurs at KI 2955 (13,17-dimethylnonacosane). The convention used here represents similar 13,17-dimethylalkanes as KI XX55, where the first two digits change according to the carbon backbone chain length and the significance of the last two digits represents the methyl branch pattern. The series of internal dimethylalkanes continues at peaks labeled KI 3155, 3355, and 3555 having carbon backbone chain lengths of 31, 33, and 35 carbons, respectively.

\section{Results and Discussion}

The total ion chromatograms for the 4 female Muscidifurax spp. and 3 male spp. are presented in Figure 1a 
and $1 b$, respectively. The KI values for the larger peaks are labeled on the chromatograms. The displayed chromatograms contain some overloading of major components and represent the analyses used to provide quality mass spectra of trace level hydrocarbons. Comparison of the sets of chromatograms reveals that each is distinct, and that the females contain more components than the males in each case.

Table 1 contains the listing of compounds identified in Muscidifurax species, form 29 to 39 carbon backbone chain lengths; however, there are minor components below $\mathrm{C}_{29}$ and above $\mathrm{C}_{39}$. This table contains qualitative data only, i.e., the presence or absence of a compound. The approximate quantitative amounts and structures can be inferred from Figure 1 and Table 1, which show that the $\mathrm{CHCs}$ of females are similar and the CHCs of males resemble each other, but with some differences within the sexes.

The distinguishing characteristics for females are 4 sets of triple peaks at KI 3203/3210, 3237, 3260; 3403/ 3410, 3437, 3460; 3603, 3637, 3660; and 3803, 3837, 3860. Each set of peaks are homologous series of dimethylalkanes (XX03/XX10), trimethylalkanes (XX37), and tetramethylalkanes (XX60). A few of these are present in males, though at very low levels. M. uniraptor is a unisexual species, where all members are female. The female characteristics in this species are much weaker than the other females. Curiously, it contains characteristics of both sexes, although the characteristic male peaks are present at a weaker level. Similarity in characteristics is observed for females of $M$. raptor, $M$. raptorellus, and M. uniraptor below KI 3100 in the chromatograms, and between $M$. raptorellus males and M. uniraptor females above a retention time of KI 3600.

$M$. zaraptor females can readily be identified by the large KI 3203 and 3060 peaks found in the chromatograms. M. raptor have a large $n-C_{31}$ alkane peak at 3100 , a large 3-MeC31 at KI 3175, and large female characteristic peaks at 3437 and 3637. M. raptorellus females are characterized by a large KI 3637 trimethylalkane, followed by a KI 3437 peak. M. uniraptor contains a unique pattern compared to females, with KI 3100, 3175, and 3555-63 peaks as the most intense.

The males have up to 4 sets of triple peaks, some being homologous series, at KI 3135, 3175; 3335, 335563, 3375, 3380; 3535, 3555-63, 3580; and 3735, 3755-63; 3780 , which tend to comprise internal mono- and dimethylalkane homologs, 3-methylalkanes, plus trimethylalkanes. These are less useful markers as females contain most of these, except for the XX80 trimethylalkanes. However, determining peak composition, especially for peaks in the KI XX55-63 range is difficult without GC/MS, or without long, narrow bore capillary columns. For example, the assignment of unseparated components from KI 3555 to 3563 is based solely on the results determined by EI GC/MS.

Males of $M$. zaraptor have internal monomethylalkanes at 3135 and $3-\mathrm{MeC}_{31}$ at $\mathrm{KI} 3175$ as the two most intense peaks. The largest peaks in M. raptor are KI 3100 and 3175 , similar to $M$. raptor females, but devoid of the female characteristic peaks. $M$. raptorellus males are characterized by the KI 3563 dimethylalkane peak and 3580 internal 3/7-methylene interrupted trimethylalkane as the two largest peaks in the chromatogram.

\section{Dimethylalkanes}

Muscidifurax spp. females possess 11-methylene interrupted 3,15-dimethylalkanes (KI XX03) and structurally similar 3,X-isomers on odd carbon numbered backbone chains from $C_{29}$ to $C_{37}$ as well as less prevalent 4,16dimethylalkanes (KI XX90) on even carbon backbone chains from $C_{30}$ to $C_{36}$. Generally, insects produce hydrocarbons with odd methyl branch locations on odd carbon backbones (e.g., 3,15- $\mathrm{Me}_{2} \mathrm{C}_{33}$ ) and even branch locations on even backbones (e.g., $4,16-\mathrm{Me}_{2} \mathrm{C}_{34}$ ). The occurrence of odd methyl branch locations on even backbones, although less common, still greatly outnumber the occasions where even branch locations are observed on an odd backbone chain. Exceptions do exist, such as 3,7- $\mathrm{Me}_{2} \mathrm{C}_{30}$ observed in M. zaraptor females at KI 3110.

Most methylene interruptions found in insect $\mathrm{CHCs}$ have three methylene units (e.g., 11,15- and 3,7-dimethylalkanes), and to a lesser extent, odd sequences greater than three units; however, a five methylene unit interruption is rare. Bridges with even numbers of methylene units, methyls on adjacent carbons in the backbone, or a dimethyl on a single carbon in the backbone are extremely rare and were not observed in these insects.

Reports in the literature of internally branched 11methylene interrupted $\mathrm{CHC}$ s such as $11,23-\mathrm{Me}_{2} \mathrm{C}_{35}$ are common [12, 13], but there are few reports of 3,15dimethylalkanes, usually as a minor isomer within a peak containing other 3,X-isomers [14, 18, 29-32]. Muscidifurax spp. may be the first genus reported with a 3,15-isomer as a significant or sole 3,X-substituted dimethylalkane within the peak, rather than a predominant 3,7-dimethylalkane, as found typically at KI XX10 in other insects, such as Blatella cockroaches [16]. Additional 3,X-isomers with large methylene interruptions (greater than 3 methylene units) have been reported previously as 3,13- [14, 23, 30], 3,17- [14, 29], and 3,19[33] dimethylalkanes. Muscidifurax spp. do contain these isomers, but at very low levels. Previously, isomers of 4,8-, 4,10-, 4,12-, and 4,14-dimethylalkanes have been reported [12, 26, 29,34]. However, there is only one report of 4,16-dimethylalkanes, found in peaks containing 4,14- and 4,18-isomers [14]; it is not known whether the 4,16-isomer is the major component of this peak as is the case for Muscidifurax.

Figure 2 displays the EI mass spectra of 11-methylene interrupted 3,X-and 4,X-branched dimethylalkanes for backbone chain lengths from 33 to 35 carbons. In displaying these mass spectra, the mass-to-charge $x$ axis is excluded below $m / z 100$. Generally, even/odd ion pairs at $m / z 98 / 99, m / z 84 / 85$, and sequentially lower 

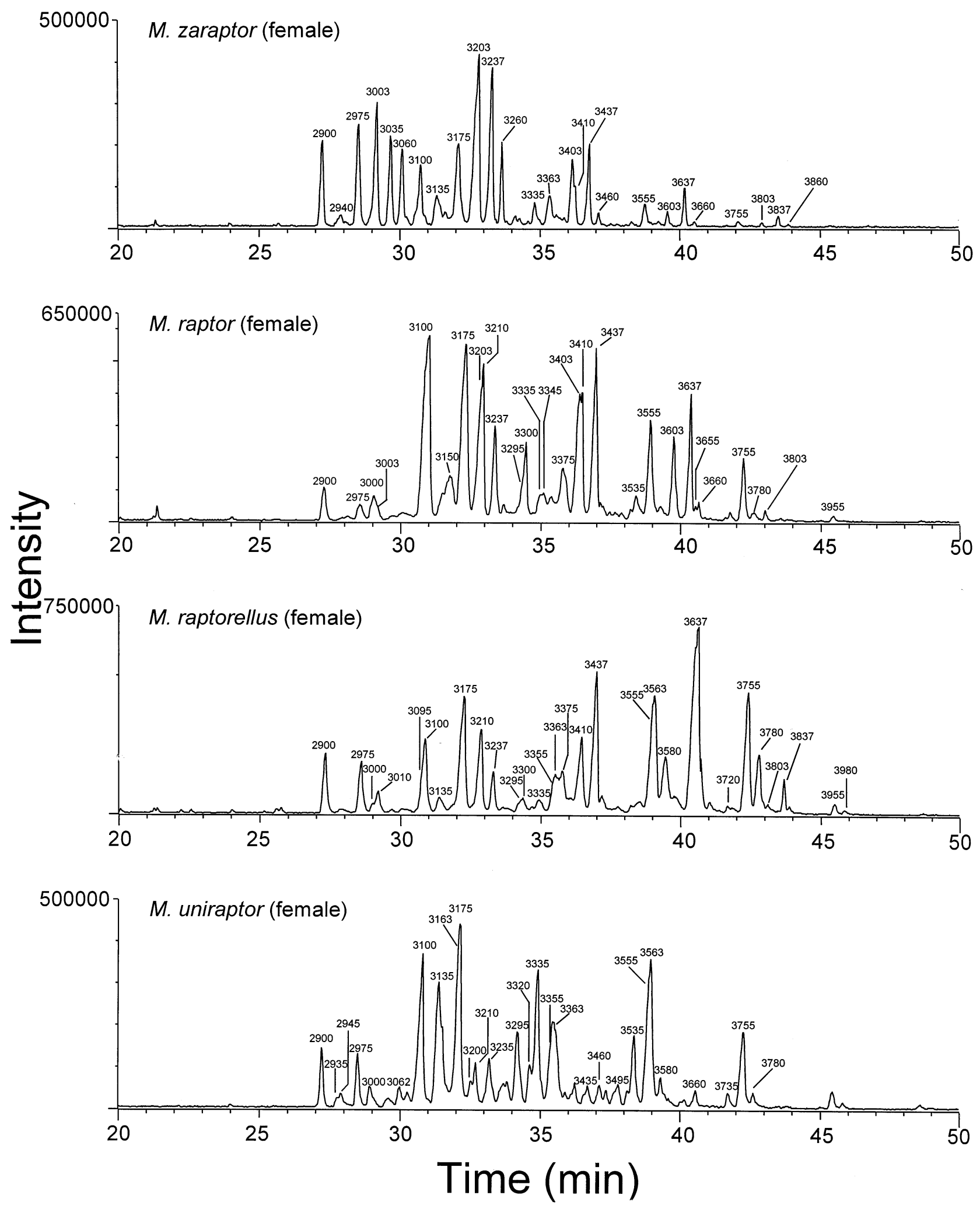

A

Figure 1. (Figure continued on next page) 

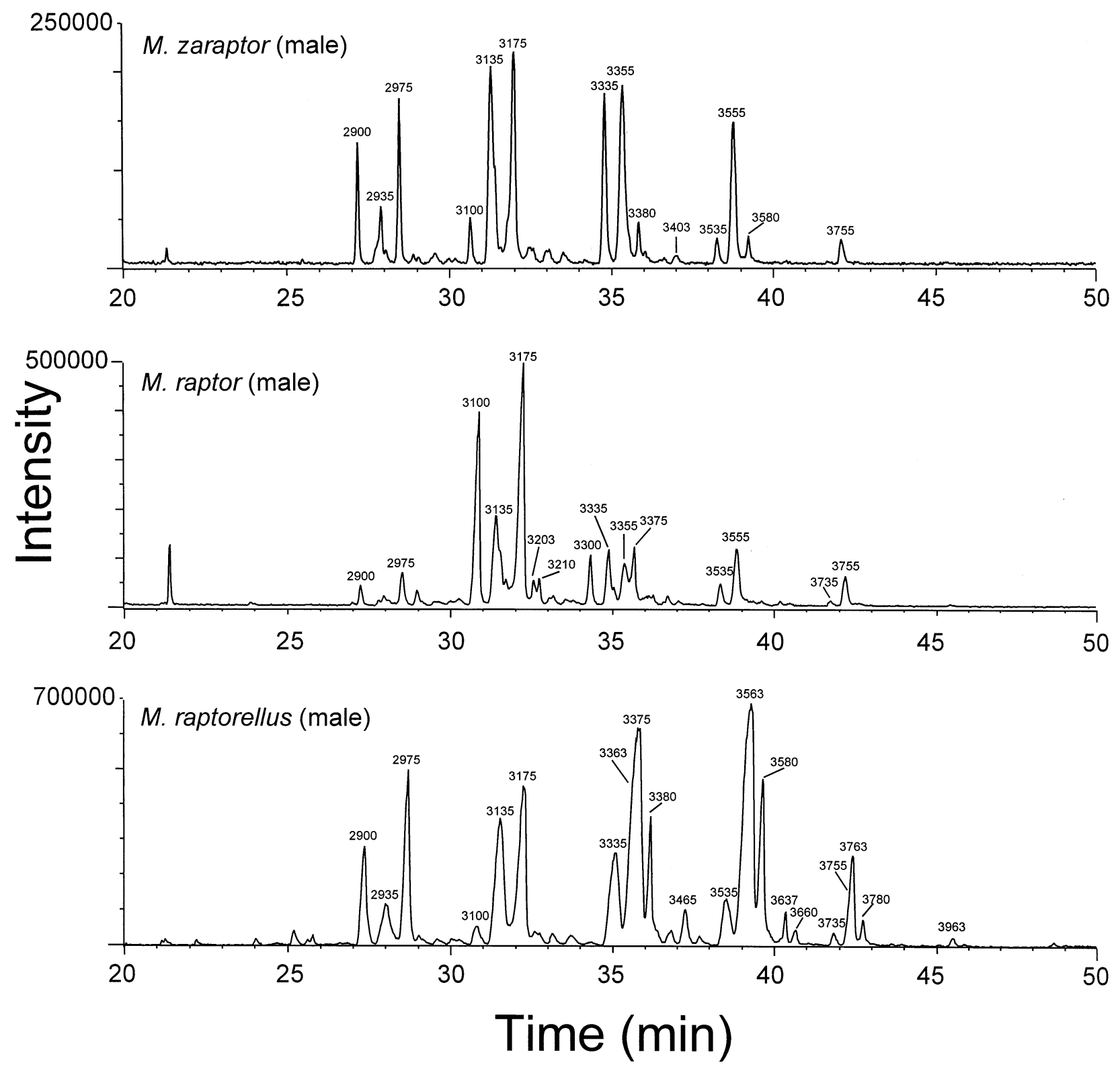

B

Figure 1 (continued from previous page). Total ion chromatograms of pooled samples containing cuticular hydrocarbons extracted from 8 to 10 insects each of (a) female Muscidifurax zaraptor, M. raptor, M. raptorellus, and M. uniraptor and (b) males of M. zaraptor, M. raptor, and M. raptorellus. The largest peaks are labeled with retention indices. Homologous series are represented by KIs with the same last two digits.

are difficult to observe due to the increased low mass fragments characteristically produced from hydrocarbons. Detecting a $m / z 56 / 57$ ion pair, theoretically indicative of a $3, X$-terminal fragment from the end with the 3-methyl branch, is virtually impossible to interpret and assign with certainty. Instead, the interpretation relies heavily on the remaining three observable secondary ion fragments. The expected fragments are listed on the structural representation included at the right side of each mass spectrum in the figure. All cleavages occur next to the tertiary carbon; the bars above and below the structure indicate which bond is cleaved and the expected fragment ion mass produced from the cleavage. In addition to these expected secondary fragmentation ions, there are additional minor primary fragment ions observed [27]. The ion pairs at $m / z 252 / 253$ in Figure 2a of 3,15- $\mathrm{Me}_{2} \mathrm{C}_{33}$ and in Figure $2 \mathrm{~b}$ of $4,16-\mathrm{Me}_{2} \mathrm{C}_{34}$, as well as the $\mathrm{m} / z 280 / 281$ pair in Figure $2 \mathrm{c}$ of $3,15-\mathrm{Me}_{2} \mathrm{C}_{35}$ are primary ions produced from $\alpha$-cleavage at the methyl branch adjacent to the terminal end that contains the larger chain.

Anomalous ions are sometimes generated by the fragmentation of large methylene interrupted hydrocarbons $[12,17,35,36]$. In particular, an artifact is pro- 
Table 1. Cuticular hydrocarbons identified in Muscidifurax uniraptor, M. raptor, M. zaraptor, and M. raptorellus ${ }^{a}$

\begin{tabular}{|c|c|c|c|c|c|c|c|c|c|}
\hline & & & $\begin{array}{c}M . \\
\text { uniraptor }\end{array}$ & $\begin{array}{l}M . \\
\text { raptor }\end{array}$ & $\begin{array}{c}M . \\
\text { raptor }\end{array}$ & $\begin{array}{c}M . \\
\text { zaraptor }\end{array}$ & $\begin{array}{c}M . \\
\text { zaraptor }\end{array}$ & $\begin{array}{c}M . \\
\text { raptorellus }\end{array}$ & $\begin{array}{c}M . \\
\text { raptorellus }\end{array}$ \\
\hline $\mathrm{KI}$ & Hydrocarbons & & q & q & 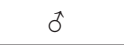 & q & t & q & $\hat{0}$ \\
\hline 2900 & & $n-C_{29}$ & + & + & + & + & + & + & + \\
\hline 2935 & $\langle\mathrm{~S}\rangle 15-,, 13-, 11-, 9-$ & $\mathrm{MeC}_{29}$ & ++++ & ---+ & ++++ & ---+ & ++++ & $\mathrm{t}+++$ & ++++ \\
\hline 2940 & 7- & $\mathrm{MeC}_{29}$ & + & + & + & + & + & + & + \\
\hline 2950 & $5-$ & $\mathrm{MeC}_{29}$ & $\mathrm{t}$ & + & + & & + & & + \\
\hline 2955 & $\langle S\rangle 13,17-$ & $\mathrm{Me}_{2} \mathrm{C}_{29}$ & & & & & & & $\mathrm{t}$ \\
\hline 2975 & $3-$ & $\mathrm{MeC}_{29}$ & + & + & + & + & + & + & + \\
\hline 3000 & & $n-C_{30}$ & + & + & + & & $\mathrm{t}$ & + & + \\
\hline 3003 & $3,15-$ & $\mathrm{Me}_{2} \mathrm{C}_{29}$ & & & & + & & & \\
\hline 3010 & $3,9-, 3,7-$ & $\mathrm{Me}_{2} \mathrm{C}_{29}$ & $\mathrm{t}+$ & $\mathrm{t}+$ & $\mathrm{t}+$ & $t+$ & $\mathrm{t}+$ & -+ & \\
\hline 3035 & $14-, 12-, 10-$ & $\mathrm{MeC}_{30}$ & $++\mathrm{t}$ & & +++ & & $--\mathrm{t}$ & & --+ \\
\hline 3037 & $3,7,15-, 3,7,11-$ & $\mathrm{Me}_{3} \mathrm{C}_{29}$ & & $-\mathrm{t}$ & & $+\mathrm{t}$ & tt & +- & \\
\hline 3040 & 8- & $\mathrm{MeC}_{30}$ & $\mathrm{t}$ & & $\mathrm{t}$ & & $\mathrm{t}$ & & + \\
\hline 3045 & $6-$ & $\mathrm{MeC}_{30}$ & + & & $\mathrm{t}$ & & & & \\
\hline 3060 & $3,7,11,15-$ & $\mathrm{Me}_{4} \mathrm{C}_{29}$ & & & & + & + & & \\
\hline 3065 & 4- & $\mathrm{MeC}_{30}$ & + & + & $\mathrm{t} ?$ & + & + & + & + \\
\hline 3070 & $6,10-$ & $\mathrm{Me}_{2} \mathrm{C}_{30}$ & + & & & & & & \\
\hline 3075 & $3-$ & $\mathrm{MeC}_{30}$ & + & + & + & + & + & + & + \\
\hline 3090 & $4,16-, 4,10-, 4,8-$ & $\mathrm{Me}_{3} \mathrm{C}_{30}$ & $-t+$ & --+ & & +-+ & --+ & $-t+$ & \\
\hline 3100 & & $n-C_{31}$ & + & + & + & + & + & + & + \\
\hline 3110 & $3,7-$ & $\mathrm{Me}_{2} \mathrm{C}_{30}$ & & & & + & & & \\
\hline 3135 & $15-, 13-, 11-, 9-$ & $\mathrm{MeC}_{31}$ & ++++ & ++++ & ++++ & ++++ & ++++ & ++++ & ++++ \\
\hline 3140 & $7-$ & $\mathrm{MeC}_{31}$ & + & + & + & + & + & + & + \\
\hline 3150 & $5-$ & $\mathrm{MeC}_{31}$ & + & + & + & + & + & + & \\
\hline 3155 & $13,17-, 11,15-, 9,13-$ & $\mathrm{Me}_{2} \mathrm{C}_{31}$ & ++- & & $-t+$ & --+ & $\mathrm{tt}+$ & $+\mathrm{t}-$ & +++ \\
\hline 3163 & $7,11-$ & $\mathrm{Me}_{2} \mathrm{C}_{31}$ & + & & + & + & + & + & + \\
\hline 3163 & $\langle\mathrm{~S}\rangle 11,21-, 9,19-$ & $\mathrm{Me}_{2} \mathrm{C}_{31}$ & ++ & & & & & & \\
\hline 3175 & $3-$ & $\mathrm{MeC}_{31}$ & + & + & + & + & + & + & + \\
\hline 3183 & $5,9-$ & $\mathrm{Me}_{2} \mathrm{C}_{31}$ & + & + & & + & + & & \\
\hline 3200 & & $n-C_{32}$ & + & + & + & & + & & + \\
\hline 3203 & $3,19-, 3,17-, 3,15-$ & $\mathrm{Me}_{2} \mathrm{C}_{31}$ & & -++ & +++ & --+ & --+ & & \\
\hline 3210 & $3,11-, 3,9-, 3,7-$ & $\mathrm{Me}_{2} \mathrm{C}_{31}$ & $-\mathrm{t}+$ & $-t+$ & $-t+$ & $\mathrm{tt}+$ & $\mathrm{t}-+$ & +++ & $-t+$ \\
\hline 3235 & $16-, 14-, 12-, 10-$ & $\mathrm{MeC}_{32}$ & ++++ & & -+-- & & $--t-$ & & -+++ \\
\hline 3237 & $3,7,15-, 3,7,11-$ & $\mathrm{Me}_{3} \mathrm{C}_{31}$ & -+ & -+ & -+ & ++ & ++ & ++ & \\
\hline 3240 & 8- & $\mathrm{MeC}_{32}$ & $\mathrm{t}$ & & & & & & \\
\hline 3245 & $6-$ & $\mathrm{MeC}_{32}$ & + & + & & & & & \\
\hline 3260 & $8,12-$ & $\mathrm{Me}_{2} \mathrm{C}_{32}$ & + & & & & & & \\
\hline 3260 & $3,7,11,15-$ & $\mathrm{Me}_{4} \mathrm{C}_{31}$ & & & & + & $\mathrm{t}$ & & \\
\hline 3265 & $10,22-, 9,21-, 8,20-$ & $\mathrm{Me}_{2} \mathrm{C}_{32}$ & & & & & & & +++ \\
\hline 3265 & 4- & $\mathrm{MeC}_{32}$ & + & + & $\mathrm{t}$ & & & $\mathrm{t}$ & \\
\hline 3270 & $6,10-$ & $\mathrm{Me}_{2} \mathrm{C}_{32}$ & + & & & & & & \\
\hline 3275 & $3-$ & $\mathrm{MeC}_{32}$ & & $\mathrm{t}$ & + & & & & \\
\hline 3290 & $4,16-, 4,8-$ & $\mathrm{Me}_{2} \mathrm{C}_{32}$ & -+ & ++ & & ++ & $\mathrm{t}+$ & -+ & \\
\hline 3300 & & $n-\mathrm{C}_{33}$ & + & + & + & + & & + & \\
\hline 3320 & $4,8,16-, 4,8,12-$ & $\mathrm{Me}_{3} \mathrm{C}_{32}$ & -+ & ++ & & -+ & & ++ & \\
\hline 3335 & $\langle\mathrm{~S}\rangle 17-, 15-, 13-, 11-, 9-$ & $\mathrm{MeC}_{33}$ & +++++ & +++++ & +++++ & +++++ & +++++ & ++++- & ++++- \\
\hline 3340 & 7- & $\mathrm{MeC}_{33}$ & + & + & + & + & & & \\
\hline 3350 & $5-$ & $\mathrm{MeC}_{33}$ & + & + & + & & & & \\
\hline 3355 & $\langle\mathrm{~S}\rangle 15,19-, 13,17-, 11,15-, 9,13-$ & $\mathrm{Me}_{2} \mathrm{C}_{33}$ & ++++ & ++++ & ++++ & ++++ & ++++ & ++++ & ---+ \\
\hline 3363 & $7,11-$ & $\mathrm{Me}_{2} \mathrm{C}_{33}$ & + & & + & & + & & \\
\hline 3363 & $11,21-,\langle S\rangle 11,23-, 9,21-$ & $\mathrm{Me}_{2} \mathrm{C}_{33}$ & +++ & & +++ & +-- & +-- & +-- & $++\mathrm{t}$ \\
\hline 3375 & 3- & $\mathrm{MeC}_{33}$ & + & + & + & + & + & + & + \\
\hline 3380 & $11,15,23-, 9,13,21-, 9,13,23-$ & $\mathrm{Me}_{3} \mathrm{C}_{33}$ & $-+\mathrm{t}$ & & $-\mathrm{t}-$ & $\mathrm{tt}-$ & $\mathrm{t}+-$ & $\mathrm{t}--$ & ++- \\
\hline 3383 & 5,9 & $\mathrm{Me}_{2} \mathrm{C}_{33}$ & & + & & + & & & \\
\hline 3385 & $7,11,15-$ & $\mathrm{Me}_{3} \mathrm{C}_{33}$ & $\mathrm{t} ?$ & & & & & $\mathrm{t} ?$ & \\
\hline 3400 & & $n-C_{34}$ & & & & & $\mathrm{t}$ & & \\
\hline 3403 & $3,15-, 3,13-$ & $\mathrm{Me}_{2} \mathrm{C}_{33}$ & ++ & $+\mathrm{t}$ & +- & $+\mathrm{t}$ & +- & +- & \\
\hline 3410 & $3,9-, 3,7-$ & $\mathrm{Me}_{2} \mathrm{C}_{33}$ & $\mathrm{t}+$ & ++ & $\mathrm{t}+$ & $\mathrm{t}+$ & & $\mathrm{t}+$ & \\
\hline 3435 & $17-, 16-, 14-, 12-$ & $\mathrm{MeC}_{34}$ & +++- & & --+- & & & & --++ \\
\hline 3437 & $3,7,15-, 3,7,13-, 3,7,11-$ & $\mathrm{Me}_{3} \mathrm{C}_{33}$ & $\mathrm{tt}+$ & $+\mathrm{t}-$ & +-- & +-- & $\mathrm{t}--$ & +-+ & $+-\mathrm{t}$ \\
\hline 3440 & 8- & $\mathrm{MeC}_{34}$ & + & & & & & & \\
\hline 3455 & $15,19-, 14,18-, 13,17-, 12,16-$ & $\mathrm{Me}_{2} \mathrm{C}_{34}$ & $\mathrm{t}+--$ & -+-- & $-\mathrm{t}--$ & & & $--\mathrm{tt}$ & \\
\hline
\end{tabular}


Table 1. (continued from previous page) Cuticular hydrocarbons identified in Muscidifurax uniraptor, M. raptor, M. zaraptor, and M. raptorellus

\begin{tabular}{|c|c|c|c|c|c|c|c|c|c|}
\hline & & & $\begin{array}{c}\text { M. } \\
\text { uniraptor }\end{array}$ & $\begin{array}{l}\text { M. } \\
\text { raptor }\end{array}$ & $\begin{array}{l}M . \\
\text { raptor }\end{array}$ & $\begin{array}{c}\text { M. } \\
\text { zaraptor }\end{array}$ & $\begin{array}{c}\text { M. } \\
\text { zaraptor }\end{array}$ & $\begin{array}{c}\text { M. } \\
\text { raptorellus }\end{array}$ & $\begin{array}{c}M . \\
\text { raptorellus }\end{array}$ \\
\hline $\mathrm{KI}$ & Hydrocarbons & & q & q & 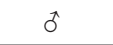 & 운 & 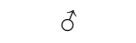 & q & 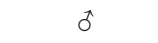 \\
\hline 3460 & $8,12-$ & $\mathrm{Me}_{2} \mathrm{C}_{34}$ & $\mathrm{t}$ & & & & & & \\
\hline 3460 & $3,7,11,15-$ & $\mathrm{Me}_{4} \mathrm{C}_{33}$ & + & + & & + & & + & \\
\hline 3465 & $12,22-, 11,21-$ & $\mathrm{Me}_{2} \mathrm{C}_{34}$ & & & & & & & ++ \\
\hline 3465 & 4- & $\mathrm{MeC}_{34}$ & & + & & & & & \\
\hline 3470 & $6,16-, 6,14-, 6,10-$ & $\mathrm{Me}_{3} \mathrm{C}_{34}$ & $-t+$ & +++ & & & & & \\
\hline 3490 & $4,16-, 4,14-, 4,8-$ & $\mathrm{Me}_{3} \mathrm{C}_{34}$ & -++ & +-+ & & $\mathrm{t}--$ & & $\mathrm{t}-+$ & \\
\hline 3495 & $10,14,22-, 6,10,14-$ & $\mathrm{Me}_{3} \mathrm{C}_{34}$ & -+ & & & & & & +- \\
\hline 3520 & $4,8,16-, 4,8,14-, 4,8,12-$ & $\mathrm{Me}_{3} \mathrm{C}_{34}$ & $-t+$ & +-- & & & & +-+ & \\
\hline 3535 & $17-, 15-, 13-, 11-, 9-$ & $\mathrm{MeC}_{35}$ & ++++- & +++- & +++-- & -+++-- & +++-- & ++++- & ++++- \\
\hline 3540 & $7-$ & $\mathrm{MeC}_{35}$ & & + & & & & & \\
\hline 3555 & $15,19-, 13,17-, 11,15-$ & $\mathrm{Me}_{2} \mathrm{C}_{35}$ & $++\mathrm{t}$ & $++\mathrm{t}$ & +++ & +++ & +++ & +++ & \\
\hline 3563 & $\langle\mathrm{~S}\rangle 13,23-, 11,21-, 9,19-$ & $\mathrm{Me}_{2} \mathrm{C}_{35}$ & & +++ & ++- & & & ++- & ++- \\
\hline 3563 & $11,23-, 9,21-$ & $\mathrm{Me}_{2} \mathrm{C}_{35}$ & ++ & & & & & & +- \\
\hline 3570 & $7,21-, 7,19-, 7,15-$ & $\mathrm{Me}_{2} \mathrm{C}_{35}$ & -+- & & +-- & $--\mathrm{t}$ & & & \\
\hline 3575 & 3- & $\mathrm{MeC}_{35}$ & & + & + & & & & \\
\hline 3580 & $\begin{array}{l}\text { 11,15,25-, 11,15,23-, } \\
11,19,23-, 11,15,19-\end{array}$ & $\mathrm{Me}_{3} \mathrm{C}_{35}$ & -+-- & -+-- & -+-- & -+-- & -+-- & $\mathrm{t} ?++\mathrm{t}$ & -+-- \\
\hline 3583 & $5,21-, 5,19-, 5,17-$ & $\mathrm{Me}_{2} \mathrm{C}_{35}$ & & $\mathrm{ttt}$ & & & & & \\
\hline 3603 & $3,15-$ & $\mathrm{Me}_{2} \mathrm{C}_{35}$ & + & + & + & + & + & + & \\
\hline 3610 & $3,9-, 3,7-$ & $\mathrm{Me}_{2} \mathrm{C}_{35}$ & & ++ & & & & -+ & \\
\hline 3635 & $16-$ & $\mathrm{MeC}_{36}$ & + & & & & & & \\
\hline 3637 & $3,7,15-, 3,7,13-$ & $\mathrm{Me}_{3} \mathrm{C}_{35}$ & $+\mathrm{t}$ & +- & +- & +- & +- & +- & +- \\
\hline 3655 & $16,20-, 15,19-, 14,18-$ & $\mathrm{Me}_{2} \mathrm{C}_{36}$ & & $\mathrm{t}++$ & & & & -++ & \\
\hline 3660 & $3,7,11,15-$ & $\mathrm{Me}_{4} \mathrm{C}_{35}$ & + & + & & + & & & \\
\hline 3665 & $13,23-, 12,22-$ & $\mathrm{Me}_{2} \mathrm{C}_{36}$ & & & & & & & ++ \\
\hline 3690 & $4,16-$ & $\mathrm{Me}_{2} \mathrm{C}_{36}$ & & + & & & & & \\
\hline 3720 & $4,8,16-$ & $\mathrm{Me}_{3} \mathrm{C}_{36}$ & & + & & & & + & \\
\hline 3735 & $\langle\mathrm{~S}\rangle 19-, 17-, 15-, 13-, 11-, 9-$ & $\mathrm{MeC}_{37}$ & ++++-- & ++++- & ++++- & -- & & ++++-+ & -++++- \\
\hline 3755 & $\begin{array}{l}\langle\mathrm{S}\rangle 17,21-, 15,19-, 13,17- \\
11,15-\end{array}$ & $\mathrm{Me}_{2} \mathrm{C}_{37}$ & ++++ & ++++ & $++\mathrm{t}-$ & $-\mathrm{tt}-$ & +++- & $++\mathrm{t}-$ & ++++ \\
\hline 3763 & $\langle\mathrm{~S}\rangle 13,25-, 11,23-$ & $\mathrm{Me}_{2} \mathrm{C}_{37}$ & ++ & & & & & ++ & ++ \\
\hline 3780 & $\begin{array}{l}\langle\mathrm{S}\rangle 15,19,23-, 13,17,21- \\
11,15,19-\end{array}$ & $\mathrm{Me}_{3} \mathrm{C}_{37}$ & & $+\mathrm{t}+$ & & & & +-+ & \\
\hline 3780 & $\begin{array}{l}\text { 13,17,25-, 11,15,23-, } \\
11,19,23-\end{array}$ & $\mathrm{Me}_{3} \mathrm{C}_{37}$ & +++ & & & & & & +++ \\
\hline 3803 & $3,19-, 3,17-, 3,15-$ & $\mathrm{Me}_{2} \mathrm{C}_{37}$ & & $+\mathrm{t}+$ & & --+ & & $--\mathrm{t}$ & \\
\hline 3837 & $3,7,15-$ & $\mathrm{Me}_{3} \mathrm{C}_{37}$ & & + & & + & & + & \\
\hline 3855 & $15,19-$ & $\mathrm{Me}_{2} \mathrm{C}_{38}$ & & & & & & + & \\
\hline 3860 & $3,7,11,15-$ & $\mathrm{Me}_{4} \mathrm{C}_{37}$ & & & & $\mathrm{t}$ & & & \\
\hline 3955 & $17,21-, 15,19-, 13,17-, 11,15-$ & $\mathrm{Me}_{2} \mathrm{C}_{39}$ & +--- & +++- & & & & +++- & ++++ \\
\hline 3963 & $13,25-, 15,25-, 13,23-$ & $\mathrm{Me}_{2} \mathrm{C}_{39}$ & +-- & & & & & & $-\mathrm{tt}$ \\
\hline 3980 & $\begin{array}{l}13,17,25-, 13,21,25- \\
15,19,23-, 13,17,21-\end{array}$ & $\mathrm{Me}_{3} \mathrm{C}_{39}$ & -+-- & & & & & $+++\mathrm{t}$ & \\
\hline
\end{tabular}

${ }^{a}$ Key: $(\langle\mathrm{S}\rangle)$ symmetrical, $(+)$ indicates that this isomer was observed, $(-)$ indicates that this isomer was not observed $(\mathrm{t})$ trace amount of component, (?) some uncertainty about the identity, KI adjusted to produce uniform indices for $\mathrm{C}_{35}$ and above, ( $(q)$ denotes female and ( $\delta$ ) denotes male.

duced at $m / z 209$ in 11-methylene interrupted hydrocarbons. This ion has been observed previously in published mass spectra [35, 36]. Normally, an ion pair would be expected at $m / z 210 / 211$ as the primary ion, having weaker intensity than the corresponding secondary ion at $m / z 239$; however, the observed ion is 1-2 Da lower than expected. It is thought to be produced from $\alpha$-cleavage exterior to the methyl branches on each end of the 11-methylene sequence rather than being produced from the $m / z 211$ primary ion. This reasoning is based on the observation of the mass-to-charge values for anomalous ions produced from other large methylene interrupted methylalkanes [12, 17]. The resulting fragment from this process may be a distonic radical cation, providing a favorable pathway for $\mathrm{H}_{2}$ elimination to produce an alkene ion, observed at $m / z$ 209. It is not known whether the charge is retained on the end where the shorter or longer chain was cleaved.

The males of this genus, as well as M. uniraptor females, also have dimethylalkanes with 11-methylene unit interruptions; however, these branches are more symmetrical (internal). Figure 3 displays two such isomers, eluting at the same KI, found in M. uniraptor. The major component is the 11,23-dimethylheptatriacontane $\left(11,23-\mathrm{Me}_{2} \mathrm{C}_{37}\right)$ isomer. The minor component of this peak is the symmetrical $13,25-\mathrm{Me}_{2} \mathrm{C}_{37}$. 

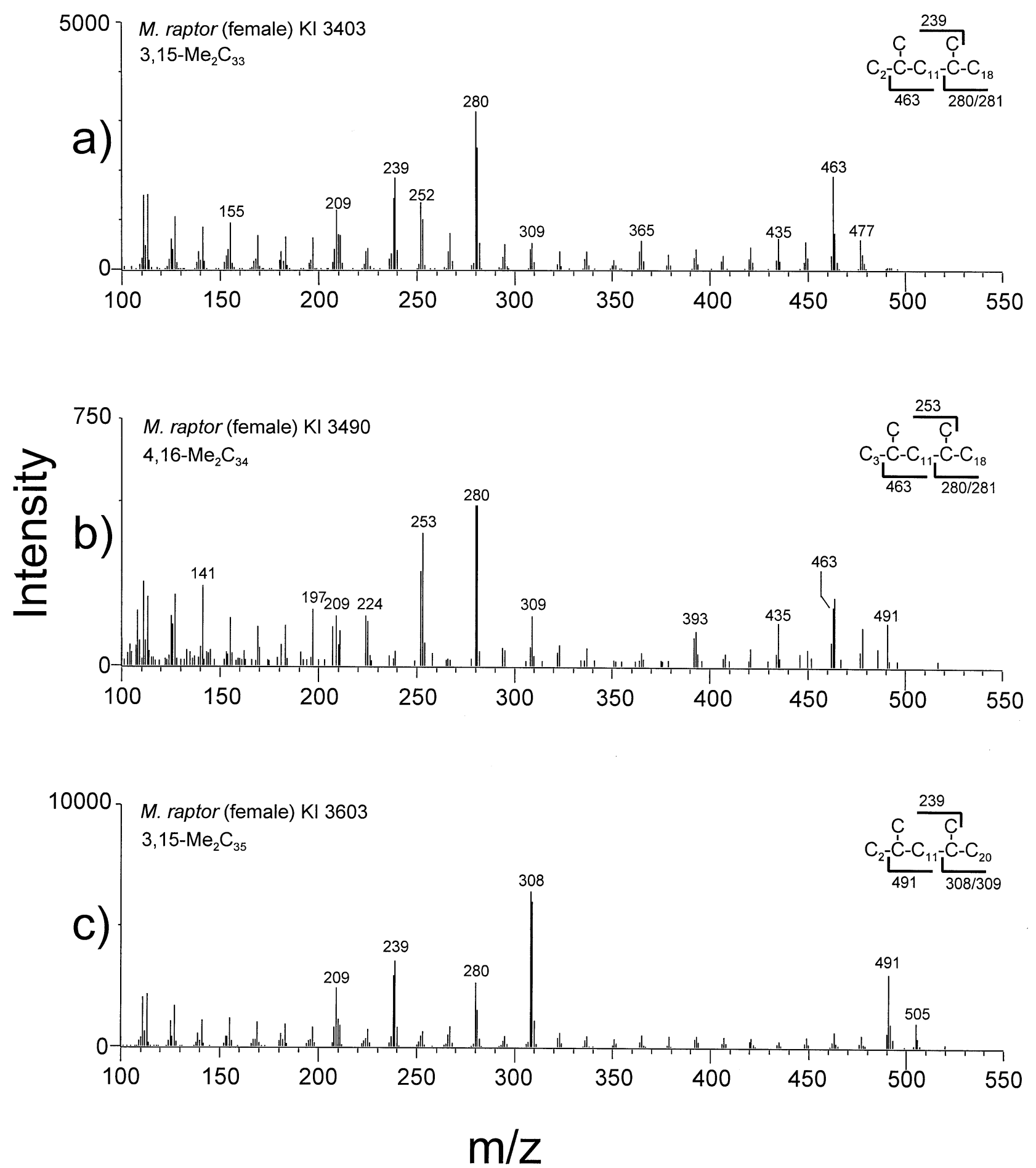

Figure 2. Mass spectra of external dimethylalkanes with 11-methylene interrupted sequences between methyl branches. These compounds are characteristic dimethylalkanes from the cuticle of Muscidifurax females. This mass spectra shown are: (a) 3,15- $\mathrm{Me}_{2} \mathrm{C}_{33}$ from the $\mathrm{KI} 3403$ peak of $M$. raptor, (b) 4,16- $\mathrm{Me}_{2} \mathrm{C}_{34}$ from the KI 3490 peak and of $M$. raptor, and (c) 3,15- $\mathrm{Me}_{2} \mathrm{C}_{35}$ from the KI 3603 peak of M. raptor.

\section{Trimethylalkanes}

Females of Muscidifurax, with the exception of M. uniraptor, have large 3/7-methylene interrupted 3,7,15trimethylalkanes. The pattern demonstrates retention of methyl branches at carbons 3 and 15 from the dimethylalkane, with the addition of a methyl branch 3-methylene units inside the external 3-position to produce the trimethylalkane. If this were a random process, the presence of 7/3-methylene sequenced 3,11,15-trimeth- 


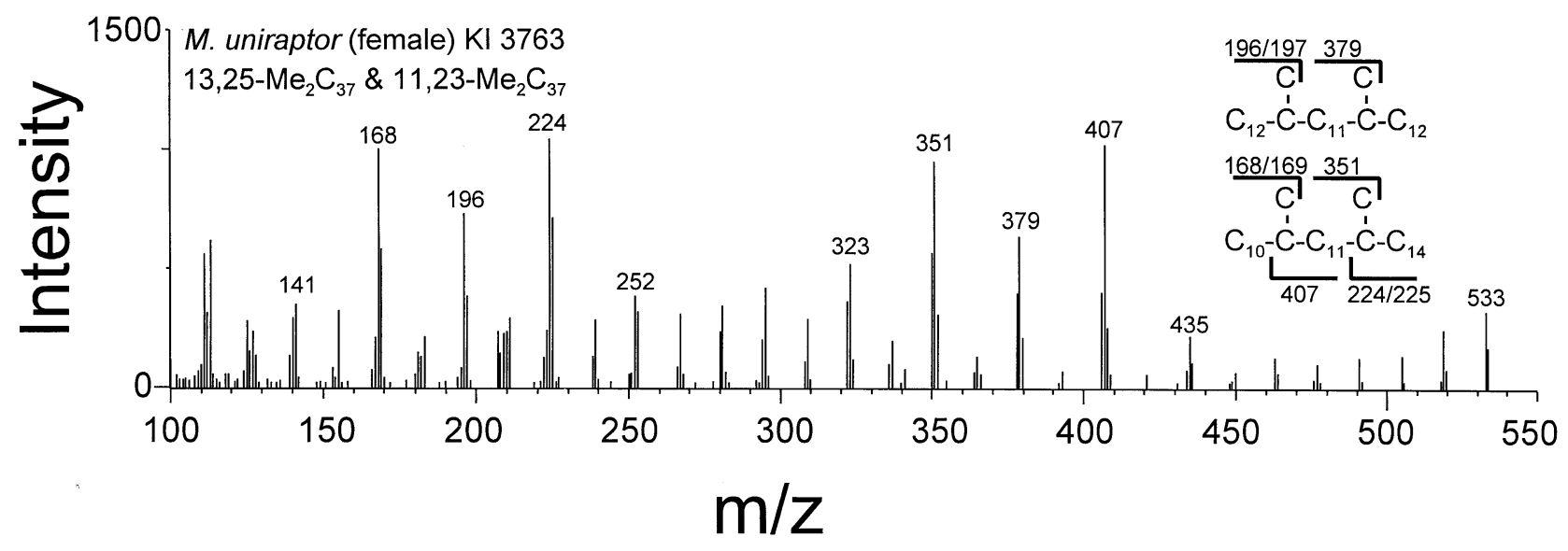

Figure 3. Mass spectrum of internal dimethylalkanes with 11-methylene interrupted sequences between methyl branches. These compounds are characteristic dimethylalkanes from the cuticle of Muscidifurax males and M. uniraptor females. The mass spectrum shown is from the KI 3763 peak of M. uniraptor containing a mixture of $13,25-\mathrm{Me}_{2} \mathrm{C}_{37}$ and $11,23-\mathrm{Me}_{2} \mathrm{C}_{37}$.

ylalkanes would be expected; however, isomers with this branching pattern were not observed in these insects.

The 3/7-methylene interrupted examples presented here are 4,8,16- $\mathrm{Me}_{3} \mathrm{C}_{34}$ (Figure 4a), 3,7,15- $\mathrm{Me}_{3} \mathrm{C}_{35}$ (Figure $4 \mathrm{~b}$ ), and $4,8,16-\mathrm{Me}_{3} \mathrm{C}_{36}$ (Figure $4 \mathrm{c}$ ). These examples are drawn from $M$. raptor and $M$. raptorellus females. Even-backboned analogs are generally less prevalent than the odd-backboned species, but usually follow a similar methylene interruption pattern. Because of the lower abundance of even-backboned species typically observed in insect CHCs, mass spectra of these even analogs are reported less often. Insects of the genus Muscidifurax are one of the two genera reported to-date which have a clearly definable 3,7,15-trimethylalkane series as well as corresponding 4,8,16-trimethylalkanes on even carbon backbone chains. The only other insects reported to produce a 3,7,15-trimethylalkane are lps pine engraver beetles [14]. Although not presented in these figures, 3,7,11- and 4,8,12-trimethylalkanes were observed in Muscidifurax; however, these are present at low levels and have been found in several other insects $[12,26,29,37]$.

The males also contain 3/7-methylene interrupted trimethylalkanes, characteristic of this genus, but there are two important factors that differentiate them from the females. Males possess internally branched trimethylalkanes rather than an external 3,7,15-isomer as found in the females. For example, chromatograms of male $M$. raptorellus have a peak at KI 3380 containing two isomers: $11,15,23-\mathrm{Me}_{3} \mathrm{C}_{33}$ and 9,13,21- $\mathrm{Me}_{3} \mathrm{C}_{33}$ (Figure 5a).

Secondly, multiple 3/7-methylene interrupted isomers of comparable abundance may be found under one peak. There are some exceptions where males contain only one isomer, such as for the KI 3580 peak in M. zaraptor males (Figure $5 b$ ), just as there are cases where females may contain trace amounts of other
$3 /$ X-methylene interrupted isomers in addition to the 3,7,15-trimethylalkane. The KI 3780 peak in M. raptorellus males consists of three isomers (Figure $5 \mathrm{c}$ ). In this case, a third isomer of weaker intensity has a 7/3methylene interruption pattern. This pattern was not observed in female trimethylalkanes, but has been observed in the CHCs and cuticular alcohols of other insects as a 5,13,17-methyl branched isomer [26, 36]. Males do not have even-backbone analogs of these 3/7-methylene interrupted internal methyl-branched alkanes except for $10,14,22-\mathrm{Me}_{3} \mathrm{C}_{34}$ found at $\mathrm{KI} 3495$ in $M$. raptorellus. Trimethylalkanes with 3/3-methylene interruptions, such as 13,17,21- and 11,15,19-isomers in Muscidifurax, are very common in insects.

\section{Tetramethylalkanes}

The final pair of mass spectra (Figure 6) clearly show the presence of tetramethylalkanes in Muscidifurax females. The 3,7,11,15- $\mathrm{Me}_{4} \mathrm{C}_{33}$ of $M$. raptor (KI 3460) (Figure 6a) and 3,7,11,15- $\mathrm{Me}_{4} \mathrm{C}_{33}$ of $M$. zaraptor (KI 3660) (Figure 6b) are presented as excellent examples of the unmistakable mass spectra obtained. Observations of tetramethylalkanes in insects are rare, and when present, these hydrocarbons are typically of low abundance. Female $M$. zaraptor contain the largest amounts of tetramethylalkanes, starting with a large peak at KI 3060 and ending at KI 3860. These represent tetramethylalkanes on carbon backbone chains of $\mathrm{C}_{29}$ to $\mathrm{C}_{37}$. Only two other insects have been reported to contain 3,7,11,15-tetramethylalkanes; these are the tsetse fly Glossina brevipalpis [13] and the pine engraver beetle lps paraconfusus [14].

An artifact is observed in the mass spectra displayed in Figure 6b. Usually, the even mass of an even/odd pair of fragments is indicative of a terminal hydrocarbon fragment. The $m / z 266 / 267$ ion pair results from $\alpha$-cleavage external to the methyl branch at carbon 15 in 

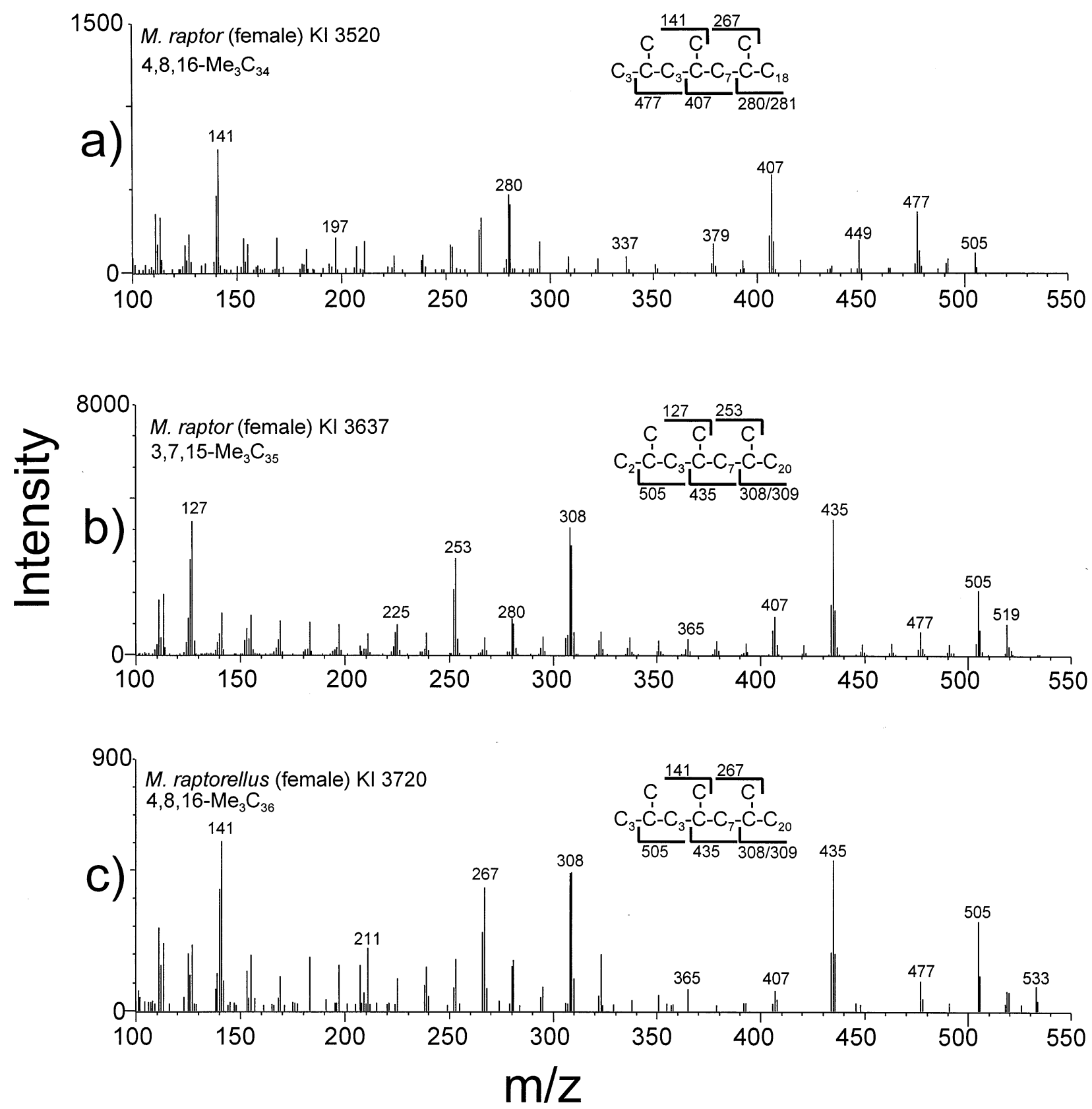

Figure 4. Mass spectra of external trimethylalkanes with 3/7-methylene interrupted sequences between methyl branches. These compounds are characteristic trimethylalkanes from the cuticle of Muscidifurax females. The mass spectra shown are: (a) 4,8,16- $\mathrm{Me}_{3} \mathrm{C}_{34}$ from the $\mathrm{KI} 3520$ peak of $M$. raptor, (b) 3,7,15- $\mathrm{Me}_{3} \mathrm{C}_{35}$ from the KI 3637 peak of $M$. raptor, and (c) 4,8,16- $\mathrm{Me}_{3} \mathrm{C}_{36}$ from the $\mathrm{KI} 3720$ peak of $M$. raptorellus.

$3,7,11,15-\mathrm{Me}_{4} \mathrm{C}_{35}$ and therefore, is expected to produce a $m / z 267$ ion of greater intensity than $m / z 266$. This artifact is also observed in the mass spectrum of the lps pine engraver beetle for a homologous tetramethylalkane [14]. Therefore, this anomaly is most likely consistent in the mass spectrum of this compound and is not produced by the mass spectrometer or conditions of the analysis. Tetramethylalkanes were not detected in the males.

\section{Conclusions}

Both sexes of Muscidifurax contain prominent $\mathrm{CHCs}$ with rare methylene interrupted patterns. Sexual dimorphism is clearly seen by GC/MS. Female CHCs (except for those of M. uniraptor) are predominated by external 11-methylene interrupted 3,15-dimethylalkanes and 3/7-methylene interrupted 3,7,15-trimethylalkanes, culminating in 3/3/3-methylene interrupted 

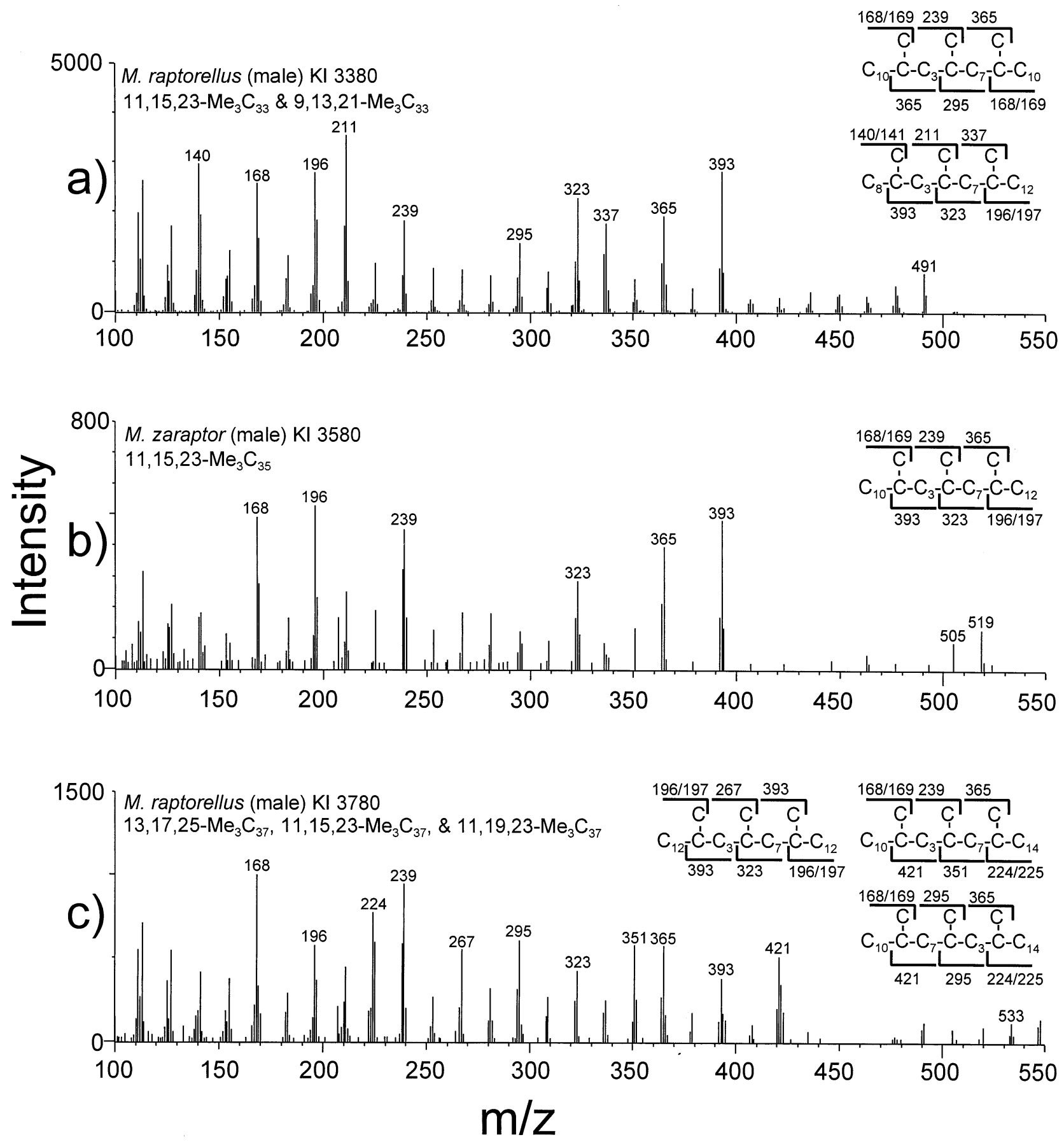

Figure 5. Mass spectra of internal trimethylalkanes with 3/7-methylene interrupted sequences between methyl branches. These compounds are characteristic trimethylalkanes from the cuticle of Muscidifurax males. The mass spectra shown are: (a) a mixture of $11,15,23-\mathrm{Me}_{3} \mathrm{C}_{33}$ and $9,13,21-\mathrm{Me}_{3} \mathrm{C}_{33}$ from the $\mathrm{KI} 3380$ peak of $M$. raptorellus, (b) 11,15,23- $\mathrm{Me}_{3} \mathrm{C}_{35}$ from the $\mathrm{KI} 3580$ peak of $M$. zaraptor, and (c) a mixture of $13,17,25-\mathrm{Me}_{3} \mathrm{C}_{37}, 11,15,23-\mathrm{Me}_{3} \mathrm{C}_{37}$, and a rare $7 / 3$-methylene sequenced $11,19,23-$ $\mathrm{Me}_{3} \mathrm{C}_{37}$ from the KI 3780 peak of $M$. raptorellus.

3,7,11,15-tetramethylalkanes, all with odd carbon chain backbones. Some of the even backboned analogs of these can be found in the females, such as 4,16-dimethylalkanes and 4,8,16-trimethylalkanes; however, evidence was not found for an even backboned tetramethylalkane. Male CHCs have internal 11-methylene interrupted 11,23-dimethylalkanes, and 3/7-methylene interrupted 11,15,23-trimethylalkanes, but no tetramethylalkanes are observed in the males.

M. uniraptor is the most difficult member of the genus to identify morphologically and is thought to have originated when populations of a related species, perhaps $M$. raptorellus, acquired a Wohlbachia bacterial symbiont that produces the unisexual trait [38, 39]. 


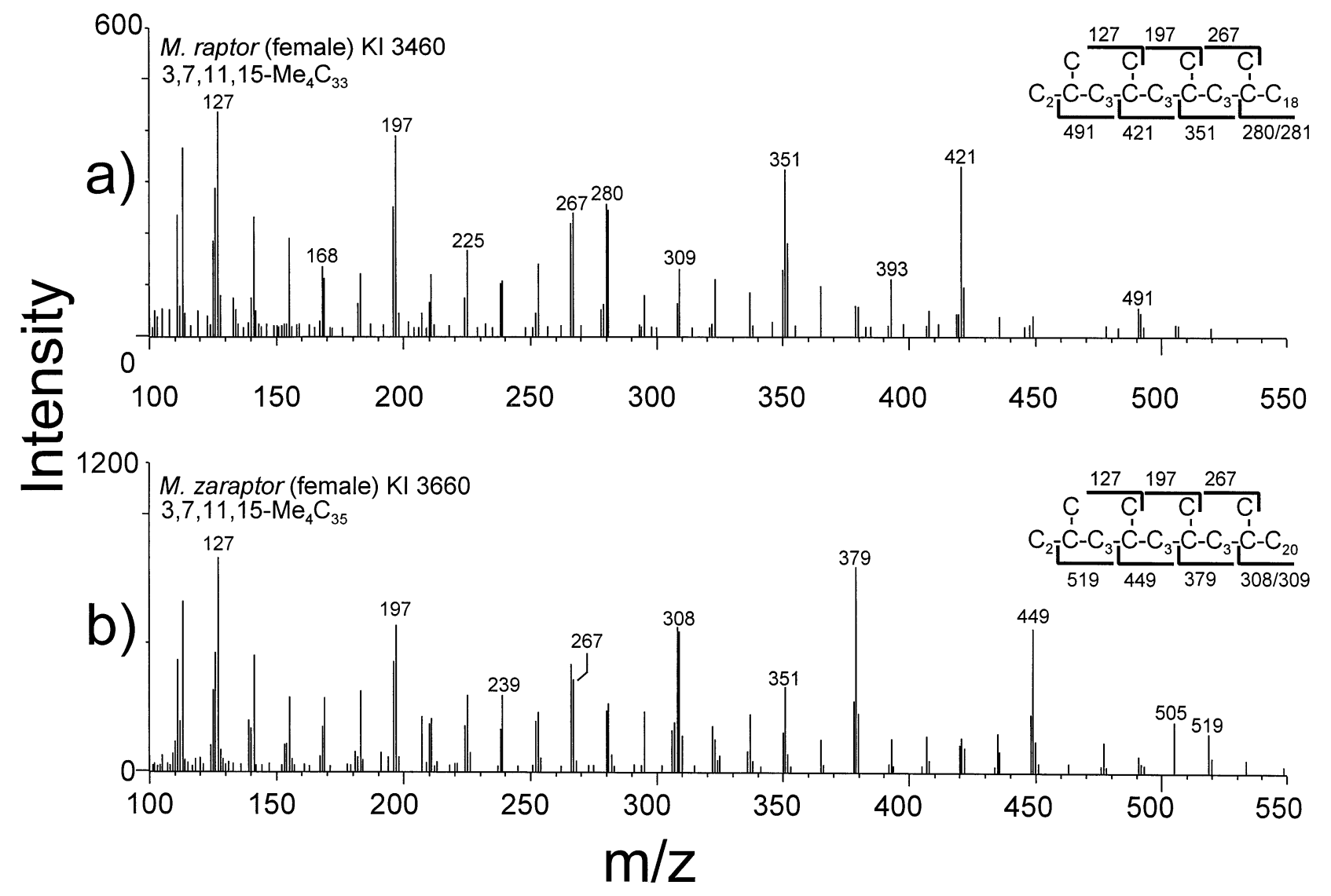

Figure 6. Mass spectra of external tetramethylalkanes observed in females of Muscidifurax. The mass spectra shown are: (a) 3,7,11,15- $\mathrm{Me}_{4} \mathrm{C}_{33}$ from the KI 3460 peak of $M$. raptor and (b) 3,7,11,15- $\mathrm{Me}_{4} \mathrm{C}_{35}$ from the KI 3660 peak of $M$. zaraptor.

Some characters or components link M. uniraptor to the females, whereas other characters link this species to males, in particular $M$. raptorellus males. For example, the composition of internal trimethylalkanes are identical at KI 3780 in M. uniraptor females and M. raptorellus males. It is possible that, given the absence of males in this species, selection has been relaxed for the presence of the full compliment of hydrocarbon components involved in mate recognition. If this is the case, $M$. uniraptor females may be in transition back towards the simpler CHC pattern found in males of the other species.

The mass spectral data from females indicate that the biochemical processes leading to production of $\mathrm{CHCs}$ are most similar in $M$. raptor and M. zaraptor, while $M$. raptorellus appear more distantly related; $M$. uniraptor are least similar but appear to be related more to $M$. raptorellus than $M$. raptor or $M$. zaraptor. This tends to agree with the results of mitochondrial DNA [8]. Neither the diet of parasitoids nor seasonal effects are expected to significantly alter the observed CHCs. It is believed that the production of CHCs is genetically based. Using characteristics and quantitation from GC for speciation of single females as well as examining patterns from various collection locations is addressed more closely with the analysis of single Muscidifurax by Geden et al. [9]. Care should be taken, however, in basing phylogenetic classification solely on compounds that are observed.

This work may ultimately prove most useful in the examination of hydrocarbons from larvae, where an assessment of colony species contamination can be made prior to eclosion of adult wasps. Chemotaxonomic characters derived solely from GC peak areas can also be used to produce a key to examine parasitic wasps for accidental mixing of species among colonies [9].

\section{Acknowledgments}

The authors thank M. Y. Hosack for sample preparation, J. J. Petersen for supplying $M$. raptorellus, and S. Penn for supplying M. zaraptor. The authors also thank C. C. Grimm, M. M. Booth, and J. A. Hogsette for critically reviewing this manuscript.

\section{References}

1. Geden, C. J.; Steinkraus, D. C.; Miller, R. W.; Rutz, D. A. Environ. Entomol. 1992, 21, 1419-1426.

2. Petersen, J. J.; Cawthra, J. K. Biol. Control 1995, 5, 279-84. 
3. Rueda, L. M.; Axtell, R. C. N. C. Agric. Res. Serv. Tech. Bull. 1985, 278, 1-88.

4. Kogan, M.; Legner, E. F. Can. Entomol. 1970, 102, 1268-90.

5. Kawooya, J. K. Ph.D. Dissertation, University of Illinois at Champaign-Urbana, 1983.

6. Propp, G. D. Misc. Publ. Entomol. Soc. Am. 1986, 61, 164-174.

7. Antolin, M. F.; Guertin, D. S.; Petersen, J. J. Biol. Control 1996, $6,76-82$.

8. Taylor, D. B.; Peterson, R. D.; Szalanski, A. L.; Petersen, J. J. Ann. Entomol. Soc. Am. 1997, 90, 814-824.

9. Geden, C. J.; Bernier, U. R.; Carlson, D. A.; Sutton, B. D. Biol. Control, in press.

10. Carlson, D. A.; Mayer, M. S.; Silhacek, D. L.; James, J. D.; Beroza, M.; Bierl, B. A. Science 1971, 174, 76-78.

11. Carlson, D. A.; Nelson, D. R.; Langley, P. A.; Coates, T. W.; Davis, T. L.; Leegwater-van der Linden, M. J. Chem. Ecol. 1984, 10, 429-450.

12. Nelson, D. R.; Carlson, D. A. Insect Biochem. 1986, 16, 403-416.

13. Nelson, D. R.; Carlson, D. A.; Fatland, C. L. J. Chem. Ecol. 1988, 14, 963-987.

14. Page, M.; Nelson, L. J.; Blomquist, G. J.; Seybold, S. J. J. Chem. Ecol. 1997, 23, 1053-99.

15. Carlson, D. A.; Service, M. W. Science 1980, 207, 1089-1091.

16. Brenner, R. J.; Carlson, D. A.; Roth, L. M.; Patterson, R. S. Invert. Taxon. 1993, 7, 1205-1219.

17. Nelson, D. R.; Nunn, N. J.; Jackson, L. L. Insect Biochem. 1984, $6,677-683$.

18. Sutton, B. D.; Carlson, D. A.; Lockwood, J. A.; Nunamaker, R. A. J. Orthop. Res. 1996, 5, 1-12.

19. Takahashi, S.; Grassa, A. J. Chem. Ecol. 1985, 21, 1837-45.

20. Haverty, M. I.; Collins, M. C.; Nelson, L. J.; Thorne, B. L. J. Chem. Ecol. 1997, 23, 927-965.
21. Lavine, B.; Carlson, D. A. Anal. Chem. 1987, 59, 469A-470A.

22. Lavine, B.; Carlson, D. A.; Henry, D.; Jurs, P. C. J. Chemometrics 1988, 2, 29-37.

23. Sutton, B. D.; Carlson, D. A. Arch. Insect Biochem Physiol. 1993, $23,53-65$.

24. Carlson, D. A.; Milstrey, S. K.; Narang, S. K. Bull. Entomol. Soc. 1993, 83, 507-515.

25. Nelson, D. R.; Sukkestad, D. R. Biochemistry 1970, 9, 4601-4611.

26. Nelson, D. R.; Fatland, C. L.; Howard, R. W.; McDaniel, C. A.; Blomquist, G. J. Insect Biochem. 1980, 10, 409-418.

27. Nelson, D. R.; Sukkestad, D. R.; Zaylskie, R. G. J. Lipid Res. 1972, 13, 413-421.

28. Kissin, Y. V.; Feulmer, G. P. J. Chromatogr. Sci. 1986, 24, 53-59.

29. Lockey, K. H. Insect Biochem. 1984, 14, 645-656.

30. Lockey, K. H. Insect Biochem. 1984, 14, 65-75.

31. Lockey, K. H. Comp. Biochem. Physiol. 1985, 80B, 633-640.

32. Yoder, J. A.; Blomquist, G. J.; Denlinger, D. L. Arch. Insect Biochem. Physiol. 1995, 28, 377-385.

33. Kruger, E. L.; Pappas, C. D.; Howard, R. W. J. Med. Entomol. 1991, 28, 859-864.

34. Nelson, D. R.; Dillwith, J. W.; Blomquist, G. J. Insect Biochem. 1981, 11, 187-197.

35. Nelson, D. R.; Fatland, C. L. Insect Biochem. Mol. Biol. 1992, 22, 111-123.

36. Nelson, D. R.; de Renobales, M.; Dwyer, L. A.; Zamboni, A. C.; Fatland, C. L.; Blomquist, G. J. Insect Biochem. 1989, 19, 197-208.

37. Martin, M. M.; MacConnell, J. G. Tetrahedron 1970, 26, 307-319.

38. Stouhammer, R. S.; Breeuwer, J. A. J.; Luck, R. F.; Werren, J. H. Nature 1993, 361, 66-68.

39. Stouhammer, R. S.; Luko, S.; Mak, F. Norwegian J. Agric. Sci. 1994, 16, 117-122. 